\title{
KARMAYOGA DAN KEPEMIMPINAN \\ DALAM SANTI PARWA
}

\author{
Anak Agung Gde Dira \\ Ida Bagus Made Sadu Gunawan \\ agungdira@unhi.ac.id \\ Prodi Ilmu Filsafat Hindu \\ Universitas Hindu Indonesia \\ Denpasar
}

\begin{abstract}
ABSTRAK
Dalam teks-teks yang tersirat dalam Santi Parwa kita bisa menemukan sebuah etos kerja yang memiliki tujuan spiritual. Kerja dalam Santi Parwa dihubungkan dengan pencarian jalan kebahagiaan melalui aktivitas sehari-hari yang dilakukan berdasarkan swadharma masing-masing. Dalam Santi Parwa juga dianjurkan jalan mencari kebenaran sejati dengan bekerja (karmayoga), tentu kerja yang didasari pada prinsip-prinsip dharma untuk bisa mendapatkan artha untuk tujuan moksa pencaharian kebenaran absolut. Di bawah ini akan dijelaskan prihal karmayoga, dharma dan artha sebagai prinsip atau pedoman etik kerja yang tersirat dalam teks Santi Parwa.
\end{abstract}

\section{PENDAHULUAN}

Pada zaman globalisasi ini, persoalan-persoalan etika seakan mengalami kemunduran. Nilai-nilai moral yang menjadi acuan hidup sudah kian menyusut. Orang-orang hanya mengejar kehidupan material, transaksional, sehingga moralitas dan etika hanya sebagai tempelan saja. Manusia dewasa ini makin sadar bahwa seluruh krisis di bumi ini tidak hanya disebabkan oleh alasan material tapi justru lebih pada sebab-sebab transendental. Dunia modern sekarang ini tidak lagi memiliki horizon spiritual (Hidayat, 2003:78).

Manusia modern melihat segala sesuatu hanya dari sudut pandang pinggiran eksistensi, tidak pada 'pusat spiritualitas' dirinya, sehingga mengakibatkan ia lupa siapa dirinya. Perhatian yang lebih terpusat pada dunia materi memang telah memberikan kemajuan yang sangat mengagumkan. Tapi secara kualitatif dan keseluruhan tujuan hidupnya ternyata sangat dangkal. Dekadensi atau kejatuhan manusia saat ini telah kehilangan pengetahuan tentang dirinya, dan menjadi sangat tergantung pada pengetahuan eksternal, yang tidak langsung berhubungan dengan dirinya (Hidayat, 2003).

Dari persoalan di atas semakin tampak bahwa agama memang diperlukan dalam menata perilaku manusia (etika). Hal ini menjadi penting karena pengalaman manusia yang diperoleh dari ketidakpastian, ketidakberdayaan dan kelangkaan yang memang merupakan karakteristik fundamental kondisi manusia. 
Dalam ajaran agama Hindu, doktrin moral menjadi penting sebagai pedoman dalam menjalani ke kehidupan yang lebih baik di tengah kian kaburnya normanorma moral dan etika di zaman modern ini.

Banyak ajaran etika dalam agama Hindu yang kian termarjinalisasi saat ini, atau hanya sebatas dipahami secara tekstual dan tidak menemukan kontekstualisasinya. Seperti ajaran Tri Kaya Parisuda, Catur Purusa Artha, Catur Asrama, Tri Hita Karana, dan masih banyak lagi. Dalam artikel ini penulis akan menjelaskan tentang ajaran etika dalam Santi Parwa.

\section{PEMBAHASAN}

\subsection{Etika Hindu dalam Santi Parwa}

Dalam teks-teks yang tersirat dalam Santi Parwa kita bisa menemukan sebuah etos kerja yang memiliki tujuan spiritual. Kerja dalam Santi Parwa dihubungkan dengan pencarian jalan kebahagiaan melalui aktivitas sehari-hari yang dilakukan berdasarkan swadharma masing-masing. Dalam Santi Parwa juga dianjurkan jalan mencari kebenaran sejati dengan bekerja (karmayoga), tentu kerja yang didasari pada prinsip-prinsip dharma untuk bisa mendapatkan artha untuk tujuan moksa - pencaharian kebenaran absolut. Di bawah ini akan dijelaskan prihal karmayoga, dharma dan artha sebagai prinsip atau pedoman etik kerja yang tersirat dalam teks Santi Parwa.

\section{Karmayoga}

Dalam bagian pertama Santi Parwa yang disalin oleh K. Nila (1991) dijelaskan perihal upaya mencari kebenaran sejati yang dilakukan oleh para Pandawa. Hal itu berawal dari Yudistira yang mengalami guncangan bathin lalu ingin menjadi seorang pertapa dan memutuskan diri dengan hal-hal keduniawian. Dalam Hindu hal ini dikenal dengan ajaran Samnyasin. Dengan mengasingkan diri ke hutan Yudistira ingin mencari kebenaran sejati.

Namun dalam Santi Parwa dikisahkan bahwa niat Yudistira ini ditentang keras oleh saudara-saudaranya seperti Arjuna, Bima, Nakula dan Sahadewa. Keempat saudara Yudistira ini membabarkan perihal pencaharian kebenaran sejati dengan cara melaksanakan swadharma sebagai seorang ksatria dan melakukan puja terhadap para dewa. Dari hasil perdebatan mereka dapat disimak bahwa teks Santi Parwa menyiratkan satu ajaran pencaharian kebenaran yang dalam agama Hindu dikenal dengan jalan Karmayoga atau pencarian kebenaran sejati dengan jalan kerja dengan tidak mengharapkan keuntungan untuk diri sendiri (Nala, 2004:161).

Hal ini dapat disimak dari pernyataan-pernyataan Arjuna dan Bima akan pentingnya melaksanakan tugas sebagai seorang ksatria, mengumpulkan harta untuk didermakan kepada rakyat tanpa mengharapkan imbalan. Selain juga agar bisa melaksanakan upacara yadnya untuk para dewa. Arjuna dan Bima juga menafikkan sikap mengasingkan diri ke hutan untuk mencari kebenaran sejati 
tentang kehidupan. Menurut mereka dengan bekerja, memimpin kerajaan yang berhasil di rampaskan dari tangan Kurawa, mereka bisa menjalankan tugasnya di dunia sebagaimana disiratkan dalam Veda. Berikut petikan pernyataan Bima dalam Santi Parwa.

"Babi rusa dan burung tidak akan bisa mencapai surge hanya karena mengasingkan diri ke hutan. Mereka harus menghimpun berkah-berkah dengan cara lain. Apabila semua orang mencapai cita-cita hanya dengan mengabaikan kesenangan, maka gunung dan pohonlah yang terutama mencapai surga".

Lansiran pernyataan dalam santi Parwa itu ingin menunjukan bahwa mengasingkan diri ke hutan dan memutus rantai karma bukanlah jalan untuk mencari kebenaran sejati. Menurut Bima, jika memang benar demikian maka gunung dan pohon-pohon itulah yang terlebih dahulu mendapatkan surga. Apa pesan yang ingin disampaikan Bima dalam Santi Parwa adalah pencarian kebenaran juga bisa dilakukan dengan jalan lain. Salah satunya adalah Karmayoga - atau jalan kerja. Ini bisa ditempuh dengan melaksanakan swadharma sebagai seorang ksatria sejati. Dalam Santi Parwa juga diistilahkan dengan kehidupan Grhasta. Maksud dari kehidupan Grhasta bukan hanya berumah tangga, tetapi melaksanakan kewajiban di dunia sebagai manusia. Kewajiban itu dilaksanakan dengan karma atau kerja. "Betapa mungkin orang terlahir sebagai seorang ksatria, mengabdikan diri kepada tugas sebagai seorang ksatria, dan telah melindungi diri ke dalam kewarganegaraannya, tiba-tiba lalu balik mencela kewajiban-kewajiban yang dibeirkan kepada wargana itu", demikian kata-kata Bima.

Anjuran melaksanakan Karmayoga juga disampaikan dengan tegas oleh Arjuna. Bahkan Arjuna dalam percakapan itu secara gamblang membahas tentang pentingnya Artha dalam kehidupan manusia untuk mencapai kesejahteraan. Dengan Artha manusia bisa menggelar upacara-upacara keagamaan yang diperuntukkan kepada para dewa. Berikut pernyataan Arjuna.

"Dengan harta maka pahala baik dari perbuatan keagamaan dapat meningkat. Orang miskin mana mungkin bisa memiliki dunia, baik di dunia ini maupun dunia akhirat. Orang miskin tidak akan berhasil melaksanakan upacara-upacara keagamaan, karena semua upacara dilandasi pelaksanaannya oleh harta kekayaan seperti ibaratnya sungaisungai bersumber dari gunung". (Nila, 1991:17).

Dari kutipan di atas terlihat Arjuna menyarankan sebuah kehidupan yang tidak memungkiri hal-hal keduniawian dalam hidup. Harta kekayaan diperlukan dalam kehidupan ini untuk bisa menggelar upacara-upacara keagamaan. Di sini dalam Santi Parwa tetap ditekankan bahwa harta tidak diperuntukkan untuk mencari kekuasaan, melainkan dipersembahkan untuk para dewa dalam bentuk ritual dan untuk mensejahterakan masyarakat. Jalan yang ditempuh untuk itu adalah Grhasta. Bukan memutuskan diri dari hal-hal keduniawian sebagaimana yang dikehendaki Yudistira. "Belajar, mengajar, berkorban, dan membantu untuk kesejahteraan orang lain, itulah tugas utama kita", kata Arjuna. Semua ini bisa dicapai dengan jalan Karmayoga - kerja. 


\section{Dharma dan Artha}

Dalam ajaran agama Hindu, dikenal dengan Catur Purusartha yang bagianbagiannya adalah dharma, artha, kama dan moksa. Menurut Nala (2004:129) Catur Purusartha merupakan ajaran etika Hindu dalam mencapai kebenaran dan kebahagian sejati. Di sana dijelaskan manusia berhak mengejar kesenangan dan kenikmatan hidup (kama), memenuhi hawa nafsunya dengan segala bentuk materi atau alat pelumas lainnya (artha), tetapi hendaknya semua diperoleh melalui dharma.

Dharma, artha, dan kama merupakan tiga unsur yang tunggal, yang selalu harus dipegang teguh jika ingin meraih kebahagiaan tertinggi, yaitu moksa dalam hidup ini. bila kenikmatan melampiaskan hawa nafsu ini dilakukan dengan mempergunakan benda atau uang yang diperoleh dengan cara korupsi atau adharma, maka dalam perjalanan hidupnya dia takkan mendapatkan kebahagiaan sejati. Maka dari itu keempat unsure tersebut harus bergandengan tangan.

Dalam Santi Parwa terurai beberapa pemahanan dan ajaran etika Hindu ini. Terutama menyangkut kaidah-kaidah etik dalam melakukan pekerjaan untuk mencapai kebahagiaan sejati. Ajaran Catur Purusartha ini bisa dilakukan dengan terlebih dahulu menjalani kehidupan sebagai Grhasta. Sebagaimana diungkapkan Nakula "Melalui pola hidup Grhasta yang mulia, tiga tujuan yaitu dharma, artha dan kama tercapai".

Dharma, artha dan kama dikenal dengan istilah Tri Warga. Tiga hal ini menjadi pedoman dalam melakukan kerja untuk mencapai kebahagiaan sejati. Dalam Santi Parwa dijelaskan bahwa untuk bisa menjalani kehidupan di dunia diperlukan kama atau niat untuk bisa memperoleh sesuatu dalam konteks ini adalah artha. Artha ini pun bukanlah tujuan dalam melaksanakan kerja/kama. Kerja mesti dilakukan dengan mengedepankan prinsip-prinsip dharma kebenaran atau kebajikan. Sebuah pekerjaan dalam Hindu harus dilakukan dengan mendasarkan diri pada prinsip-prinsip kebenaran, agar bisa mencapai apa yang disebut sebagai moksa, bagian akhir dari Catur Purusartha. Jika melaksanakan pekerjaan/kama, untuk mendapatkan sebuah hasil dari pekerjaan/artha tanpa didasari dengan sikap dharma atau etika kebenaran, maka tujuan akhir/moksa tidak akan bisa tercapai. Maka dari itu hasil dari kerja/artha, juga mesti dikorbankan dan dipersembahkan kepada sesama untuk kesejahteraan manusia. Begitu juga wajib dihaturkan kepada para dewa. Berikut kutipan Santi Parwa.

"Kebaikan dunia harus didasarkan pada tri warga: dharma, artha, kama. Pengetahuan ini merupakan inti dari ucapan. Ilmu pengetahuan ini akan melindungi dunia. Di sini diajarkan tentang kaidah dan hukuman. Untuk kehidupan yang lebih baik". (Nila, 1991:96).

Dalam Santi Parwa dijelaskan pengetahuan tentang Tri Warga juga dijalani dalam menjalankan pemerintahan. Sabda prajapati ini diperuntukkan untuk seorang raja yang memerintah. Tri Warga dijadikan kaidah untuk menjalankan pemerintahan yang didasarkan pada etika kerja, pencapaian tujuan 
dengan berdasarkan pada konsep dharma. Ketiga elemen ini lantas menjadi prinsip-prinsip etika kerja dalam agama Hindu.

Dalam Hindu melakukan pekerjaan untuk cita-cita keduniawian tidaklah dilarang. Kerja bertujuan untuk mendapatkan artha. Hanya saja proses kerja mesti dibarengi dengan kaidah dharma, tanpa melakukan tindak korupsi seperti ngetrend sekarang ini. Hindu mengajarkan hasil kerja mesti dipersembahkan untuk seluruh umat manusia, untuk kebaikan dan kebajikan, untuk memuja para dewa, untuk mencapai kebahagiaan sejati. Jadi di sini dapat disimak bahwa Hindu bukan saja melegitimasi pada hal-hal yang transendental. Imanensi dalam kehidupan dalam bentuk kerja juga absah menurut Hindu. Dengan bekerja manusia bisa mendapatkan hasil kerja berupa artha. Namun keterlenaan pada tataran artha akan membawa manusia pada jurang kemerosotan. Maka dari itu artha bukanlah segalanya. Artha dicari untuk kebaikan bersama, mensejahterakan manusia dari kehidupan, dan melaksanakan sadana spiritual. Dengan itu pencapaian terakhir yakni moksa bisa tercapai. Begitulah prinsip dan etika kerja Hindu yang bisa diinterpretasikan dalam Santi Parwa.

\subsection{Ajaran Etika Kepemimpinan}

Kepemimpinan merupakan proses mendorong dan membantu orang lain untuk bekerjasama secara antusias, untuk mencapai tujuan yang telah ditetapkan (Gunadha, 2000:4). Menurut Martini dan Namawi pemimpin adalah mengendalikan bawahan, kemampuan ini dituntut dari setiap pemimpin sebab tanpa kemampuan tersebut, pemimpin sulit untuk melaksanakan tugas (Alex S, 1996:155). Ini berarti seorang pemimpin harus mampu mengembangkan, mempengaruhi, dan mengendalikan bawahan. Di samping itu seorang pemimpin dituntut selalu belajar untuk dirinya sendiri berkaitan dengan peningkatan moral dan disiplin yang diteladani oleh pengikutnya. Ini disebabkan seorang pemimpin berperan sebagai pembina kelompok yang dipimpin, menciptakan cara-cara yang gampang untuk membangunkan semangat kerja atau memberi kesempatan serta kemungkinan orang-orang tersebut untuk memahami apa yang harus dikerjakan dan dicapai, bagaimana caranya dan syarat-syaratnya yang harus dipenuhi (Karjadi,1981:20).

Menurut Sarwoto (1986:54 ) kepemimpinan adalah kemampuan seseorang untuk memerintah atau menguasai orang banyak". Ordway Tead sebagaimana dikutip oleh Sarwoto (1986:54) memberikan definisi yang lebih konkrit atas pengertian kepemimpinan (Leadership) sebagai "segala macam kegiatan untuk mempengaruhi orang-orang supaya mereka dalam mencapai tujuan yang mereka cita-citakan mau bersatu dan mau bekerjasama". Nampaknya definisi Ordway Tead tersebut lebih menitik beratkan pada segi rasa kepuasan dan kebahagiaan hati para pengikut (bawahan) terhadap diri seorang pemimpin (manajer).

Dalam teks Hindu sangat banyak diajarkan soal etika kepemimpinan. Menyimak sekarang ini, telah banyak terjadi penyalahgunaan kekuasaan seorang pemimpin, tidak hanya di pemerintahan, melainkan juga di instansi swasta. Maraknya tindak pidana korupsi yang sampai menyeret beberapa pemimpin di daerah membuktikan bahwa sedang ada persoalan etika kepemimpinan. Pemimpin 
tidak begitu memahami apa itu arti kepemimpinan dan bagaimana kewajiban pemimpin sesuai yang diamanatkan ajaran agama khususnya Hindu.

Dalam Santi Parwa, tema kepemimpinan menjadi hal yang sangat penting diuraikan dalam bab ini. Karena nilai-nilai etika kepemimpinan dalam Santi Parwa dirasa masih sangat relevan di terapkan di abad ke 21 ini. Dalam Santi Parwa dijabarkan bahwa inti kode etik dan kewajiban seorang pemimpin adalah melindungi segenap umat manusia. Hal ini terungkap ketika terjadi doalog antara Yudistira dan Bisma.

Yudistira meminta Bisma memberikan pedoman kepemimpinan pada dirinya. Apa yang mesti dilakukan seorang raja untuk rakyatnya secara menyeluruh, itu menjadi tema penting dalam dialog tersebut. Menurut Bisma, seorang raja pertama-tama mesti memiliki tekad menerima tanggung jawab serta kewajiban dengan tujuan membahagiakan rakyatnya, mengabdikan diri kepada dewa-dewa dan para brahmana, pengabdian tersebut dilakukan dengan rendah hati. Bisma juga menyebutkan bahwa seorang pemimpin harus bertindak cepat dalam merespon persoalan yang sedang terjadi di masyarakat, tidak hanya menunggu nasib dan takdir, karena dengan sikap menunggu itu, tujuan yang diinginkan tidak akan pernah tercapai.

Selain itu, lanjut Bisma, seorang pemimpin harus selalu berpegang teguh pada kebenaran dalam menjalankan pemerintahannya. Raja yang mengabdikan pada kebenaran akan mendapatkan kebahagiaan baik di sini maupun di dunia lain nantinya. Para rsi pun memandang kebenaran itu sebagai kekayaan mereka yang paling utama. Bagi raja kiranya ada yang lebih tegas memberikan inspirasi selain kebenaran. Berikut pernyataan Bisma dalam Santi Parwa.

"Raja yang berprestasi di segala bidang, berprilaku mulia, rendah hati, membela kebenaran dan keadilan, raja yang dorongan nafsunya terkendali, perwujudannya tampan, tidak terlalu menuntut, maka raja yang sedemikian itu tidak akan kehilangan kesejahteraannya. Dengan menegakkan hukum, dan melalui tiga hal yaitu menutup kelemahan pribadi, berusaha mengetahui kelemahan lawan, dan merahasiakan pertimbangan-pertimbangan yang disimpulkan sendiri, ditambah lagi dengan tindakan langsung apa adanya, maka raja itu akan mendapatkan kemakmuran. Apabila raja menjadi lemah, maka semua orang akan mengabaikan dirinya, tetapi sebaliknya apabila ia menjadi kejam, rakyatnya akan menderita. Karena raja harus memperhatikan kedua jenis prilaku tersebut". (Nila, 1991:750)

Dari kutipan Santi Parwa di atas dapat disimak bahwa secara etika seorang raja atau pemimpin wajib mengendalikan nafsu kekuasaan dalam diri, terutama nafsu untuk berbuat kejam terhadap rakyatnya, nafsu untuk memperkaya diri sendiri dengan melakukan perampokan hak-hak masyarakat. Seorang raja mesti apa adanya tidak terlalu banyak menuntut, rendah hati dan selalu berpegang teguh pada kebenaran. Kebenaran dimaksud sesuai dengan ajaran-ajaran kitab suci Veda dan sesuai dengan kehendak rakyatnya, karena kewajiban pemimpin adalah melindungi dan mensejahterakan segenap masyarakatnya. 
Dalam Santi Parwa juga dijelaskan perihal kewajiban seorang raja secara etika yakni selalu menghormati seorang brahmana. Menurut Bisma para brahmana adalah dewa-dewa yang hidup di dunia, apabila dipuja sebagaimana sepatutnya, mereka akan menjunjung veda-Veda dan Yadnya. Tapi mereka yang ingin mendapatkan kehormatan yang sedemikian itu, tetapi bersamaan itu juga mereka bertindak membahayakan kelestarian tribuana, maka kewajiban seorang pemimpin pula untuk memberi hukuman. Hukuman bagi seorang para brahmana yang melanggar hukum adalah diusir jauh-jauh dari wilayah kerajaan. Di sini mesti diterapkan kesetaraan hukum bagi umat manusia, namun para brahmana memiliki 'keistimewaan' dalam hukum di mata seorang pemimpin. "Paduka harus tetap membeirkan belas kasih kepada brahmana", begitu sabda Bisma.

Sesuatu yang esensial dalam menjalani peran sebagai seorang pemimpin adalah mampu sebaik-baiknya memilih para menteri, abdi dan pelayan. Seorang raja diisyaratkan untuk memberikan pelayanan dan kasih sayang kepada rakyatnya yang terdiri dari empat warna, ksatria, brahmana, waisia dan sudra. Raja yang berbudi luhur dan berbicara kebenaran akan berhasil memuaskan rakyatnya. Tetapi Santi Parwa mengingatkan, raja tidak tidak boleh terlalu mengampuni setiap orang, karena bisa menunjukkan kelemahan sebagai seorang pemimpin. Dalam kitab suci yang disusun oleh Wrhaspati menjelaskan "Apabila raja selalu member ampun, maka orang-orang yang paling rendah akan selalu mengusik dirinya, seperti pawing yang duduk di atas kepala gajah yang diiringnya". Di sini ditegaskan bahwa karakter seorang pemimpin tidak boleh lunak, mesti berpegang pada prinsip, dan memiliki ketegasan dalam menghukum seseorang yang bersalah. Namun dalam sati Parwa juga dijelaskan para pemimpin tidak boleh terlalu ganas. Ia hendaknya seperti matahari yang tidak terlalu dingin dan panas sehingga menimbulkan keringat. Berikut kutipan dalam Santi Parwa.

"Raja yang tidak mencintai rakyatnya akan menyebabkan rakyat merasa khawatir. Terhadap rakyat raja harus bersikap seperti seorang ibu terhadap anaknya yang terlahir dari rahimnya sendiri. Semua ibu akan meninggalkan semua hal yang dapat menyenangkan dirinya untuk dapat memperhatikan anak-anaknya. Raja yang baik akan membebaskan diri dari keterikatan terhadap kesenangan pribadi, dan selalu mengusahakan kebaikan rakyat. Tapi jangan sampai mengabaikan kekuatan. Raja yang kuat yang selalu memberikan hukuman kepada mereka yang bersalah, hendaknya tak usah merasa khawatir”. (Nila, 1991:77).

Santi Parwa mengajarkan raja betapa pentingnya menunjunjung tinggi kepentingan rakyat di atas kepentingan pribadinya. Ia ibarat ibu yang dalam keadaan apapun selalu memprioritaskan kebutuhan anak-anaknya. Pemimpin yang sedemikian elok dilukiskan Bisma, menjadi model pemimpin yang mampu mengantarkan rakyatnya menuju gerbang kesejahteraan jasmani dan rohani.

Tetapi seorang pemimpin dituntut selalu berpegang pada etik kepemimpinan. Seorang raja tidak diperkenankan terlalu 'intim' dengan para abdi. Raja yang dilukiskan Santi Parwa memiliki posisi yang terbentengi, independen, berwibawa, dengan cara tidak melakukan hal yang remeh temeh dengan para abdinya seperti bersenda gurau. Seorang pemimpin yang terlalu bebas bergaul 
dengan para abdi maka para abdi akan mengatasi sang pemimpin itu sendiri. Demikianlan beberapa ajaran etik Hindu soal kepemimpinan yang dibabarkan dengan sangat baik dalam percakapan antara Yudistira dan Bisma dalam Santi Parwa.

\section{PENUTUP}

Dalam teks-teks yang tersirat dalam Santi Parwa kita bisa menemukan sebuah etos kerja yang memiliki tujuan spiritual. Kerja dalam Santi Parwa dihubungkan dengan pencarian jalan kebahagiaan melalui aktivitas sehari-hari yang dilakukan berdasarkan swadharma masing-masing. Dalam Santi Parwa juga dianjurkan jalan mencari kebenaran sejati dengan bekerja (karmayoga), tentu kerja yang didasari pada prinsip-prinsip dharma untuk bisa mendapatkan artha untuk tujuan moksa pencaharian kebenaran absolut. Di bawah ini akan dijelaskan prihal karmayoga, dharma dan artha sebagai prinsip atau pedoman etik kerja yang tersirat dalam teks Santi Parwa.

\section{DAFTAR PUSTAKA}

Gorda, I Gusti Ngurah. Etika Hindu dan Prilaku Organisasi. Sekolah Tinggi Ilmu ekonomi Satya Dharma Singaraja.

Geria, I Wayan. (2000). Transformasi Kebudayaan Bali memasuki Abad XXI. Percetakan Bali. Denpasar.

Gulo, W. 2002. Metodologi Penelitian. Jakarta: Grasindo.

Hadiwijono, Harun. 1979. Sari Filsafat India. Jakarta: BPK Gunung Mulia.

Kaelan. 2005. Metode Penelitian Kualitatif Bidang Filsafat. Yogyakarta: Paradigma

Koentjaraningrat. 1985. Sejarah Teori Antropologi I. Jakarta : Unniversitas Indonesia Press.

Kattsoff, O Lois, 2004. Pengantar Filsafat. Yogyakarta: Tiara Wacana

Moleong, J Lexy, 2009. Metodologi Penelitian Kualitatif. Bandung: PT Remaja Rosdakarya

Moleong, Lexy J. 2005. Metodologi Penelitian Kualitatif. Bandung : PT Remaja Rosdakarya 
Maryaeni. 2005. Metode Penelitian Kebudayaan. Jakarta : PT Bumi Aksara

Miles, M. B. \& Huberman, A. M. 1984. Qualitatif data analysis : A source book of new methods. Beverly Hills, CA : Sage Publication.

Narbuko, Cholik. 2001. Metodologi penelitian. Jakarta : Bumi Aksara.

Nasution, S. 1988. Metodologi Penelitian Kualitatif. Bandung: Tarsito.

Netra, AA.Gde Oka. 1995. Tuntunan Dasar Agama Hindu. Jakarta : Hanuman Sakti

Netra, IB. 1974. Diklat Metodologi Penelitian. Fakultas Keguruan dan ilmu Pendidikan: UNUD Singaraja

Odgen dan Richards. 1999. Linguistik Budaya. Jakarta: PT Gramedia Pustaka Utama.

Pals, Daniel L. 2006. Cetakan ke-2. Dekontruksi Kebenaran. Yogjakarta : IRCiSoN

Pudja, Gde. 2004. Bhagwad Gita. Surabaya: Paramita.

Pandit, Nyoman S. 1994 Bhagawad Gita. Jakarta: PT Hanuman Sakti.

Prabhupada, Swami Bhaktivendanta. Bhagawad Gita Menurut Aslinya. Jakarta: Pustaka Bhaktivedanta.

Poerwadarminta. 1965. Sejarah Kebudayaan Indonesia. Jakarta : Pusat Pembinaan dan Pengembangan Bahasa Departemen Pendidikan dan Kebudayaan PN Balai Pustaka

Ratna, I Nyoman Kuta, 2004. Teori, Metode, dan Teknik Penelitian Sastra. Yogyakarta: Pustaka pelajar.

Radhakrisnan, S. 2009. Bhagawad Gita. Jogjakarta:IRCiSoD.

Majalah Sarad. 2004. Pilih-pilih Kerja Orang Bali. Denpasar: Majalah Gumi Bali

Sedyawati, Edi. 2007. Kumpulan Artikel, dikumpulkan oleh Ida Bagus Suamba. Denpasar : Program Pasca Sarjana Universitas Hindu Indonesia.

Sugiyono,2008. Metode Penelitian Pendidikan Pendekatan Kualitatif dan Kuantitataif. Bandung: Alfabeta.

Sudharta, Tjok Rai. 2001. Ajaran Moral dalam Bhagawad Gita. Surabaya: Paramita. 
Sudharta, Tjok Rai, 2003, Slokantara Untaian Ajaran Etika, Teks Terjemahan dan Ulasan Surabaya : Paramita.

Triguna, dkk. 2009. Kerja dan Swadharma. Denpasar: Lembaga Penelitian UNHI.

Strauss, Alselm dan Juliet Corbin. 2007. Dasar-dasar Penelitian Kualitatif. Yogjakarta : Pustaka Pelajar

Subagiyo, Joko. 1991. Metode Penelitian Suatu Metode dan Praktek, Jakarta, Rieneka Cipta.

Sudikan, Setya Yuwana. 1989. Penuntun Karya ilmiah, Semarang, Aneka Ilmu

Sumardjo, Jakob. 2002. Arkeologi Budaya Indonesia (Pelacakan HermeneutisHistoris terhadap Artefak-artefak Kebudayaan). Yogjakarta : CV. Qalam

Surasmi, I Gusti Ayu. 2007. Jejak Tantrayana di Bali. Bali : CV. Bali Media Adhikarsa.

Bertens, K. Dkk. 1982. Sekitar Manusia, Bunga Rampai Tentang filsafat Manusia. Jakarta: PT Gramedia.

Teuuw, A. 1993. Membaca dan Menilai Sastra Kumpulan Karangan. Jakarta: Gramedia.

Tantera Keramas, Dewa Made. 2008. Metode Penelitian Kualitatif. Surabaya: PARAMITA. 